\title{
The Social Sciences: Who Won the '90s in Scholarly Book Publishing 1
}

\author{
Stephen E. Wiberley Jr.
}

The study of prizes awarded to books in the 1990s by leading social sciences scholarly associations helps us understand the disciplines, publishing, and libraries during that decade. This article examines data on prizewinners of the American Anthropological Association, the American Educational Research Association, the Association of American Geographers, the American Political Science Association, the American Psychological Association, and the American Sociological Association. For the prizewinners, it reports the distribution of winners among publishers and universities; the extent of cross-disciplinary publishing; the degree of coauthorship; trends in library acquisitions of print versions; and accessibility of electronic versions. The University of Chicago Press ranked first among publishers, and the faculty at Harvard won more prizes than did faculty at any other institution. Library of Congress and Dewey Decimal classifications assigned to the winners show substantial cross-disciplinary interest. Sixteen percent of the books were coauthored. Library print holdings appeared to decline over the decade by approximately 20 percent; and in April 2004, 19 percent of prizewinners were available electronically.

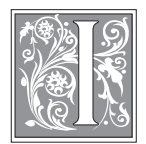

$\mathrm{n}$ a previous article on prizewinning books in the humanities, the author showed that study of those books provides insight into issues important to academic librarians and others in higher education. ${ }^{1}$ In the social sciences, the book does not dominate the scholarly literature as much as it does in the humanities. Nevertheless, books are a standard medium of communication for social scientists and, judging from prizes awarded, play a major role in anthropology, political science, and sociology. An investigation of prize-winning books in the social sciences offers data on the accomplishments of different publishers and universities, trends in library acquisitions, the extent of crossdisciplinary interest, the development of e-books, and patterns of coauthorship. These data, in turn, speak to the health of scholarly publishing, the state of the

Stephen E. Wiberley Jr. is Bibliographer for the Social Sciences and Professor in the University Library at the University of Illinois at Chicago; e-mail: wiberley@uic.edu. He thanks especially Anne M. Fleming for gathering much of the data analyzed in this article and also thanks those who supplied the names of prizewinners: Michael Murphy of the ASA, Kenneth D. Madsen, and members of the social science associations who had served on prize-selection committees. In addition, he appreciates the comments of Deborah D. Blecic, Joan B. Fiscella, and Jay Lambrecht concerning drafts of this article. 
disciplines, characteristics of American academe, and the condition of academic libraries.

One cannot say whether prize-winning books are typical of all social sciences books. There is no regular compilation of data on the number, much less the characteristics, of academic books published in the various disciplines. Until some researcher undertakes the massive effort to sample and analyze books listed in a database such as WorldCat, analysis of more readily identifiable and understandable populations such as prizewinners will have to substitute for studies of the universe of academic books. ${ }^{2}$

This article reports on prize-winning books, authors, and publishers in the social sciences from 1990 through 1999 and compares the results with the earlier study of humanities prizewinners. It covers awards given to books in six disciplines-anthropology, education, geography, political science, psychology, and sociology - by the largest American associations in each discipline. This is a reasonable approach for, as Neil J. Smelser has pointed out, career recognition and rewards in the disciplines are organized through national institutions and organizations. ${ }^{3}$ One could argue that the social sciences encompass more disciplines (for example, criminal justice or library science), but the six disciplines mentioned here were chosen because they and economics are those given primary coverage in Sources of Information in the Social Sciences: A Guide to the Literature by William $\mathrm{H}$. Webb et al. ${ }^{4}$ Though now dated in many of its particulars, Sources of Information in the Social Sciences is a landmark work for academic librarians. Economics was not included in this article because the American Economic Association does not award any prizes for books. Instead, the author studied book prizewinners from the American
Anthropological Association (AAA), the American Educational Research Association (AERA), the Association of American Geographers (AAG), the American Political Science Association (APSA), the American Psychological Association (APA), and the American Sociological Association (ASA).

Prizes studied include those awarded at the association level and those given by divisions or sections of the associations. They include both outright winners of prizes and books that received honorable mention or some similar, lesser recognition. The analysis that follows generally does not differentiate books by prize level or degree of recognition. Although this may make the analysis less nuanced than some would like, it is based on a clearly defined stratum of the population of academic books.

This article focuses on which publishers and authors (and the institutions with which the authors are affiliated) won the most prizes during the 1990s. A compilation of leading books in six of the most important disciplines in the social sciences provides an opportunity to address four additional issues of interest to librarians. First, the numbers of WorldCat holdings offers an index of the level of library acquisitions over time. Second, an analysis of netLibrary's listings of books on WorldCat provides a measure of the availability of electronic versions of leading social sciences scholarship in the early twentyfirst century. The analysis of netLibrary's WorldCat listings also indicates which publishers had books available electronically and what disciplines were best represented with e-books. Third, there is evidence that the extent of coauthorship is generally increasing in the scholarly world. ${ }^{5}$ The data set gathered for the present study provides one recent measure of coauthorship in the social sciences. Finally, by looking at the classification 
numbers assigned to prizewinners, one can assess cross-disciplinary interest in different fields.

\section{The Prizes}

At one time or another during the 1990s, the sections and interest groups of the AAA awarded eight differently named prizes to books seventy-two times and to authors eighty-three times (counts of books and authors include those that won more than one prize for the same book); the AERA and its divisions awarded three prizes to books sixteen times and to authors twenty-two times; the AAG and its specialty groups awarded three prizes to books fourteen times and to authors sixteen times; the APSA and its sections awarded twenty-four prizes to books 154 times and to authors 189 times; the APA and its divisions awarded four prizes to books fifteen times and to authors seventeen times; and, finally, the ASA and its sections awarded twenty-four prizes to books 141 times and to authors 167 times. ${ }^{6}$ In all, 412 prizes were awarded, including fifty-eight that went to books awarded more than one prize. (Twentysix books won two prizes; two books won three.) The median number of times each prize was awarded to books is five; the mean is 6.2. Nine prizes were awarded only once, all of which were established in 1997 or later, including six in 1999. The Society for Humanistic Anthropology, a section of the AAA, awarded its Turner prize to thirty-five books, including honorable mentions. Probably the most important observation to be made about the distribution of awards among the six disciplines is that nearly 90 percent went to anthropology, political science, and sociology. This raises the possibility that books are more important for these fields than for education, geography, and psychology. The number of refereed journals in the different disciplines also points to preferences for format of publication. According to Ulrich's Periodicals Directory, in the United States in 2003 (search made Dec. 13, 2003), there were 111 refereed journals in anthropology, 612 in education, 49 in geography, 224 in political science, 502 in psychology, and 198 in sociology. Distributions of prizes and refereed journals suggest that books are more important to anthropology, political science, and sociology than to education and psychology and that journals are more important to the latter pair than the former three. Prize and refereed-journal data also point to geography's relative standing among the disciplines. The number of doctoral programs in the different fields also indicates geography's place. In 1995, the National Research Council (NRC) ranked 36 programs in geography, 69 in anthropology, 95 in sociology, 98 in political science, and 185 in psychology. ${ }^{7}$

A total of 444 different authors wrote the 382 books that won one or more prizes, a mean of 1.2 authors per book. Sixty books (or $16 \%$ of the 382 books that won one or more prizes) had coauthors, a total of 134 persons or 2.2 authors per coauthored book. Because two coauthored books won prizes from two associations, an exact comparison cannot be made between coauthorship in individual disciplines and coauthorship among all prizewinners. Nevertheless, except for education (25\%) and geography (7\%), the proportions of coauthored prizewinners in the fields studied were close to the overall 16 percent (15\% for anthropology; $17 \%$ for political science; $13 \%$ for psychology; and $12 \%$ for sociology). Coauthorship among the humanities prizewinners was 7 percent, less than half of that for the social sciences (Humanities, 358).

Most social science awardees won only one prize. However, forty-one authors won two prizes, three won three prizes, and one won four. These forty-five 
authors represent 10 percent of the 444 different persons who won prizes. This contrasts with seven authors ( $2 \%$ ) out of 365 who won more than one humanities prize (Humanities, 359). Besides the fact that a larger percentage of social sciences books won multiple prizes than did humanities books, five social sciences books won prizes from more than one disciplinary association and no humanities book did. Two books won prizes from APSA and ASA, two from AAA and ASA, and one from AERA and APSA. Twelve authors won prizes for two different books in the social sciences, whereas only two humanities authors won prizes for two different books (Humanities, 359). Both of the authors of two different prize-winning humanities books worked with a coauthor on one of their two books. And the four books all received the Mildenberger Prize for a work in the field of teaching foreign languages and literatures, a subject close to the social sciences. Of the twelve social sciences authors who won prizes for two different books, three coauthored both their books, three wrote one alone and coauthored the other, and five wrote both of their books alone. These data suggest the possibility that coauthorship and work in the social sciences lead to greater output. Studies across careers of social scientists and humanities scholars would allow assessment of the effect of coauthorship on productivity and whether differences in output relate to area of study.

\section{Institutional Affiliations of Prizewinners}

The fact that 444 different authors won prizes points to the challenge librarians face in learning about individual scholars. Institutional affiliations show some predominant universities, although there is considerable scatter. In all, the investigator found 188 institutions with at least one prize. Eight prizes went to scholars identified as independent, and one prize was awarded posthumously (four of the eight prizes went to two independent authors). Fifty-eight percent of all prizes went to persons affiliated with the top 20 percent of institutions that won the most prizes. (See table 1.) This distribution is notably short of the classic distribution where 80 percent of the instances of a phenomenon come from 20 percent of the supplying sources. But 58 percent is in line with the 52 percent of affiliated humanities winners who came from the top 20 percent of institutions (Humanities, 359). Harvard was the most-laureled institution with fifteen prizes. The University of California-Berkeley, UCLA, and Yale tied for runner-up with fourteen prizes each. Berkeley, UCLA, and Yale also were among the top four institutions among humanities prizewinners; Harvard won the sixth greatest number of humanities prizes in the 1990s. Three of the University of California's campuses were among the top humanities institutions (Santa Barbara along with Berkeley and Los Angeles), and the University of California does even better in the social sciences, with six among the top twenty-two: Berkeley, Los Angeles, San Diego, Davis, Santa Barbara, and Santa Cruz. The upper Midwest was rather weakly represented among humanities prizewinners; except for the University of Chicago in the top ten, only Iowa, Ohio State, and Wisconsin-Madison were among the top nineteen (Humanities, 360). But among the social sciences, Michigan is sixth, Wisconsin is eighth, Chicago and Northwestern are among four tied for fourteenth, and Indiana and Minnesota are among five tied for eighteenth. The East and West Coasts continue to be strong as Duke, Rutgers plus five Ivy League universities, and Stanford plus six University of California campuses each took seven top spots. Excluding Duke, the only southern school 


\begin{tabular}{|c|c|c|c|c|c|c|c|}
\hline & Soci & al Sciences & $\begin{array}{r}\text { TABLE } \\
\text { rizes Aw }\end{array}$ & $\begin{array}{l}1 \\
\text { arded to I }\end{array}$ & stitutic & & \\
\hline Institution & Total & $\underset{\text { (Anthropology) }}{\text { AAA }}$ & $\begin{array}{c}\text { AERA } \\
\text { (Education) }\end{array}$ & $\underset{\text { (Geography) }}{\text { AAG }}$ & $\begin{array}{c}\text { APSA } \\
\text { (Political } \\
\text { Science) }\end{array}$ & $\underset{\text { (Psychology) }}{\text { APA }}$ & $\underset{\text { (Sociology) }}{\text { ASA }}$ \\
\hline Harvard & 15 & & & & 11 & 2 & 2 \\
\hline UC-Berkeley & 14 & 4 & 1 & 1 & 2 & & 6 \\
\hline UCLA & 14 & 1 & & & 7 & & 6 \\
\hline Yale & 14 & & 1 & & 11 & & 2 \\
\hline UC-San Diego & 13 & 1 & & & 8 & & 4 \\
\hline Michigan & 12 & 3 & 1 & & 1 & & 7 \\
\hline Stanford & 11 & & 1 & & 8 & 1 & 1 \\
\hline Wisconsin & 10 & 1 & & 1 & 5 & & 3 \\
\hline Duke & 9 & 2 & & & 5 & & 2 \\
\hline Princeton & 9 & & & & 5 & 1 & 3 \\
\hline Columbia & 8 & & 1 & & 4 & 1 & 2 \\
\hline Pennsylvania & 8 & 3 & & & 1 & & 4 \\
\hline Rutgers & 8 & 1 & & & 4 & & 3 \\
\hline Chicago & 7 & & & & 2 & & 5 \\
\hline Northwestern & 7 & 1 & & & 2 & & 4 \\
\hline UC-Davis & 7 & 1 & & & 3 & & 3 \\
\hline UC-Santa Barbara & 7 & 2 & & & & & 5 \\
\hline Colorado & 6 & 1 & & & 5 & & \\
\hline Indiana & 6 & 1 & & & 3 & & 2 \\
\hline Minnesota & 6 & & 1 & 1 & 2 & & 2 \\
\hline Texas & 6 & 3 & & 1 & 1 & & 1 \\
\hline UC-Santa Cruz & 6 & 2 & & & 1 & & 3 \\
\hline 6 with 5 & 30 & & & & & & \\
\hline 3 with 4 & 12 & & & & & & \\
\hline 14 with 3 & 42 & & & & & & \\
\hline 29 with 2 & 58 & & & & & & \\
\hline 115 with 1 & 115 & & & & & & \\
\hline Total & 460 & & & & & & \\
\hline \multicolumn{8}{|c|}{$\begin{array}{l}\text { In counting winners by institution, the investigator applied the following rules. If two or more coauthors } \\
\text { from the same institution won a prize, one prize was counted for that institution. Twenty-five such cases } \\
\text { occurred. Otherwise, the investigator counted the institution of each coauthor. Nine prizewinners either } \\
\text { identified as independent or the investigator could not find their institutional affiliation. } \\
\text { Source: See endnote } 6 \text {. }\end{array}$} \\
\hline
\end{tabular}

among top prizewinners is the University of Texas at Austin. Duke, Texas-Austin, and Virginia were the only top southern prizewinners in the humanities study. Public universities have a slightly greater presence among top prizewinners in the social sciences than in the humanities. More than half of the top humanities in- stitutions (ten of nineteen) were private, compared to about 40 percent of the top social sciences institutions (nine of twenty-two). The addition of Princeton and Northwestern among the top social sciences prizewinners does not offset the loss of New York University, Brandeis, and Cornell (Humanities, 360). 
Given that the AERA, the AAG, and the APA awarded fewer than twenty prizes each, it would have been stunning if any institution had won at least one prize from all six associations. No institution did win one from all six, but the University of California-Berkeley won in all fields except psychology; and six universities-Michigan, Stanford, Wisconsin, Columbia, Minnesota, and Texas-won prizes from four different associations. Harvard and Yale won eleven APSA prizes, the most for a single institution from a single association. The University of California-San Diego and Stanford had eight, the third most from one association, again in political science. The highest number of prizes given to one institution by ASA was seven to Michigan; the high number given to one institution by AAA was four to the University of California-Berkeley.

Although no one would measure the strength of an institution's social sciences programs by number of prizes won, it is interesting to compare the present study's findings with an institutional ranking derived from the National Research Council's Research-Doctorate Programs in the United States. Given that about 90 percent of the prizes come from AAA, APSA, and ASA, it is reasonable to derive an institutional ranking appropriate to the data on prizes by combining the NRC rankings of the anthropology, political science, and sociology programs. Table 2 gives those rankings for all institutions that had their anthropology, political science, and sociology programs in the top thirty for each discipline. There is almost complete coincidence among the

\begin{tabular}{|c|c|c|c|c|c|c|c|}
\hline \multicolumn{8}{|c|}{$\begin{array}{c}\text { TABLE } 2 \\
\text { Research-Doctorate Program Rankings }\end{array}$} \\
\hline & \multicolumn{3}{|c|}{ Rank of Program } & \multirow[b]{2}{*}{$\begin{array}{l}\text { Composite } \\
\text { Score }\end{array}$} & \multirow[b]{2}{*}{$\begin{array}{c}\text { Composite } \\
\text { Rank }\end{array}$} & \multirow[b]{2}{*}{$\begin{array}{l}\text { Prizes } \\
\text { Won }\end{array}$} & \multirow[b]{2}{*}{$\begin{array}{r}\text { Prize Rank } \\
\text { (top } 19 \text { only) }\end{array}$} \\
\hline Institution & Anthropology & \begin{tabular}{|l|} 
Political \\
Science
\end{tabular} & Sociology & & & & \\
\hline California-Berkeley & 3 & 2 & 3 & 8 & 1 & 14 & 2 (Tie) \\
\hline Chicago & 1.5 & 6 & 1 & 8.5 & 2 & 7 & 14 (Tie) \\
\hline Michigan & 1.5 & 3.5 & 4 & 9 & 3 & 12 & 6 \\
\hline Harvard & 4 & 1 & 7 & 12 & 4 & 15 & 1 \\
\hline Stanford & 7 & 5 & 8 & 20 & 5 & 11 & 7 \\
\hline UCLA & 9 & 8 & 5 & 22 & 6 & 14 & 2 (Tie) \\
\hline Wisconsin & 18.5 & 10 & 2 & 30.5 & 7 & 10 & 8 \\
\hline Yale & 9 & 3.5 & 19 & 31.5 & 8 & 14 & 2 (Tie) \\
\hline California-San Diego & 9 & 9 & 22 & 40 & 9 & 13 & 5 \\
\hline Columbia & 16 & 16 & 15 & 47 & 10 (Tie) & 8 & 11 (Tie) \\
\hline Princeton & 27 & 7 & 13 & 47 & 10 (Tie) & 9 & 9 (Tie) \\
\hline Texas & 12 & 19 & 16 & 47 & 10 (Tie) & 6 & 18 (Tie) \\
\hline Duke & 18.5 & 14 & 20 & 52.5 & 13 & 9 & 9 (Tie) \\
\hline North Carolina & 29 & 18 & 6 & 53 & 14 & 5 & $23 \quad$ (Tie) \\
\hline Johns Hopkins & 21.5 & 21 & 17 & 59.5 & 15 & 4 & 29 (Tie) \\
\hline Indiana & 29 & 20 & 12 & 61 & 16 & 6 & $18 \quad$ (Tie) \\
\hline Washington & 29 & 23 & 10 & 62 & 17 & 2 & $46 \quad$ (Tie) \\
\hline $\begin{array}{l}\text { University of Illinois- } \\
\text { Urbana Champaign }\end{array}$ & 14 & 30 & 29 & 73 & 18 & 3 & 32 (Tie) \\
\hline
\end{tabular}


top ten in each list. Only the University of Chicago, second in the composite NRC ranking, misses the top ten in prizes. Otherwise, fourteen of the eighteen that make the NRC ranking are among the top twenty-two in prizes won. Of those top prize-winning institutions that are not in the NRC rankings, Pennsylvania and Santa Barbara lacked a top thirty NRC ranking in political science, Rutgers was not in the top thirty in sociology, Northwestern and Minnesota in anthropology, University of California-Davis in political science and sociology, and Colorado and University of California-Santa Cruz in all three. As was true of a comparison of humanities prizewinners with the NRC rankings of humanities programs, a similar comparison for the social sciences reinforces something that is very well known: most of the best research comes from large research universities. And it also is true for both the humanities and social sciences that there is remarkable coincidence between the composite ranking and the institutional prize totals. Nevertheless, the dominance of private universities among the very top of the NRC rankings in the humanities - eight to two-does not hold up in the social sciences, where five of the ten, including three University of California campuses, are public universities. Furthermore, Michigan and Wisconsin, along with the University of Chicago, give the Midwest a presence in the top ten NRC rankings it lacked in the humanities where only Chicago was represented (Humanities, 361).

\section{Prize-winning Publishers}

The distribution of prizes in the social sciences among publishers is more concentrated than for institutions. (See table 3.) Fourteen presses ( $20 \%$ of all prize-winning publishers) published 67 percent of the prizewinners, whereas 20 percent of the institutions supplied 58 percent of the authors. Among 1990s humanities prize- winners, 21 percent of the publishers garnered 72 percent of the awards, whereas 20 percent of institutions supplied 52 percent of the authors (Humanities, 359, 362-63). In other words, the concentration of publishers was slightly greater in the humanities.

The University of Chicago Press leads the way in the social sciences with forty prize-winning books. Publishers that produced ten or more prizewinners in both the social sciences and the humanities include California with 63 (36 social science, 27 humanities), Princeton with 61 (38, 23), Chicago with $60(40,20)$, Cambridge with $55(29,26)$, Harvard with $40(28,12)$, Cornell with $38(17,21)$, and Oxford with $35(18,17)$. Unlike the humanities, where only one trade publisher, Norton, was in the top eighteen, three trade publishers are in the top twenty in the social sciences: Routledge (tenth), and Basic Books and Westview Press (both tied for sixteenth). A foundation press, Russell Sage, also ties for sixteenth. In the humanities, only five books won more than one prize, two of which were published by trade publishers (Humanities, 359, 363). In the social sciences, twenty-eight books won more than one prize, only three of which were published by trade presses (Routledge with two books and Crown with one). Except for one published by the Brookings Institution, all the rest were published by university presses. Harvard University Press led the way with five, followed by Chicago with four and California, Princeton, and Yale with three.

Other research reported in the library literature offers indicators of the quality of university press publications and those of trade publishers. Edward A. Goedeken found that between 1983 and 1992, the percentage of academic presses whose books received an Outstanding Academic Book award from Choice rose from 33 to 48 percent of all those so honored. ${ }^{8}$ In 


\begin{tabular}{|c|c|c|c|c|c|c|c|}
\hline & & Social Scien & $\begin{array}{r}\text { TABL } \\
\text { es Prizes } \\
\end{array}$ & $\begin{array}{l}\text { E } 3 \\
\text { Won by Pu }\end{array}$ & blishers & & \\
\hline Publisher & & Anthropology & Education & Geography & \begin{tabular}{|l|} 
Political \\
Science
\end{tabular} & Psychology & Sociology \\
\hline Chicago & 40 & 6 & 0 & 1 & 12 & 0 & 21 \\
\hline Princeton & 38 & 5 & 0 & 0 & 26 & 0 & 7 \\
\hline California & 36 & 9 & 0 & 2 & 2 & 0 & 23 \\
\hline Cambridge & 29 & 4 & 0 & 1 & 12 & 1 & 11 \\
\hline Harvard & 28 & 1 & 0 & 0 & 13 & 2 & 12 \\
\hline Yale & 25 & 3 & 3 & 1 & 15 & 0 & 3 \\
\hline Oxford & 18 & 0 & 3 & 0 & 7 & 1 & 7 \\
\hline Cornell & 17 & 4 & 0 & 0 & 10 & 0 & 3 \\
\hline Temple & 10 & 0 & 0 & 0 & 4 & 1 & 5 \\
\hline Routledge & 8 & 3 & 0 & 0 & 2 & 0 & 3 \\
\hline Illinois & 7 & 2 & 0 & 0 & 1 & 0 & 4 \\
\hline Johns Hopkins & 7 & 0 & 0 & 2 & 4 & 0 & 1 \\
\hline Kansas & 7 & 0 & 1 & 0 & 5 & 0 & 1 \\
\hline Michigan & 7 & 0 & 1 & 0 & 5 & 1 & 0 \\
\hline Minnesota & 7 & 1 & 1 & 0 & 1 & 0 & 4 \\
\hline Basic Books & 6 & 1 & 0 & 0 & 2 & 2 & 1 \\
\hline Columbia & 6 & 5 & 0 & 0 & 0 & 1 & 0 \\
\hline Russell Sage & 6 & 0 & 1 & 0 & 1 & 0 & 4 \\
\hline SUNY & 6 & 1 & 0 & 0 & 2 & 0 & 3 \\
\hline Westview & 6 & 1 & 0 & 0 & 1 & 1 & 3 \\
\hline Texas & 5 & 2 & 0 & 2 & 1 & 0 & 0 \\
\hline 5 with 4 & 20 & & & & & & \\
\hline 9 with 3 & 27 & & & & & & \\
\hline 11 with 2 & 22 & & & & & & \\
\hline 26 with 1 & 26 & & & & & & \\
\hline TOTAL & 414 & & & & & & \\
\hline
\end{tabular}

this study of social science prizewinners, university presses are 50 percent ( 36 of 72 ) of all publishers whose books won prizes. This is quite close to university presses constituting 48 percent of all presses that published Choice prizewinners. In terms of percentage of books, there is a similarity between the dominance of university presses in the social sciences and in the humanities. In the humanities, 84 percent of books that won prizes were from university presses, whereas 81 percent (336 of 414) of the prizes to books in the social sciences were awarded to university presses (Humanities, 364). The vital role of university presses in humanities and social sciences scholarship is clear.

In late 1994 and early 1995, Paul Metz and John Stemmer asked collection development librarians to rate the quality 
of sixty-four publishers, including six university presses. ${ }^{9}$ Among them, the presses include some that try to cover, to some extent, all academic areas; some that specialize in the humanities; and some that specialize in the sciences or social sciences. Twenty presses studied by Metz and Stemmer won prizes in the 1990s in the social sciences. The presses that ranked in the top four in quality in the Metz-Stemmer study were Harvard, Cambridge, Oxford, and Stanford. The first three of these publishers won eighteen prizes or more. (See table 3.) In contrast, Stanford had only four awards. Three trade publishers ranked lower in quality than Stanford in the Metz-Stemmer study, yet won more prizes. Routledge gained eight awards, Basic Books six, and Westview six. Metz-Stemmer respondents also rated the quality of Smithsonian Institution Press (one prize) and Brookings Institution Press (four prizes) higher than Routledge, Basic, and
Westview. SUNY Press, a six prizewinner, rated below the quality of Stanford, Smithsonian, and Brookings. Because trade publishers did not have comparable success in winning multiple humanities prizes and SUNY Press won only one humanities prize, there is greater coincidence between the Metz-Stemmer quality rankings and the hierarchy of humanities prize-winning publishers than between the Metz-Stemmer quality rankings and the hierarchy of social science prize-winning publishers.

\section{Disciplinary and Cross-disciplinary Trends}

Cross-disciplinary interest and borrowing among the social sciences is a well-documented phenomenon..$^{10}$ Given the interdisciplinarity of the social sciences, one would expect to find the six disciplinary associations studied here awarding substantial numbers of prizes outside their home disciplines. Assign-

\begin{tabular}{|c|c|c|c|c|c|c|c|c|c|}
\hline \multicolumn{10}{|c|}{$\begin{array}{c}\text { TABLE } 4 \\
\text { Subject Distribution of Social Sciences Prize-winners by LCC and } D D C\end{array}$} \\
\hline $\begin{array}{c}\text { Awarding } \\
\text { Association }\end{array}$ & $\begin{array}{l}\text { Anthropology } \\
\text { GN-GT } \\
300-309 \\
390-399\end{array}$ & $\begin{array}{l}\text { Education } \\
\text { L-LT } \\
370-379\end{array}$ & $\begin{array}{l}\text { Geography } \\
\text { G-GF } \\
910-919\end{array}$ & 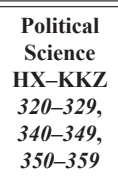 & $\begin{array}{l}\text { Psychology } \\
\text { BF } \\
150-159\end{array}$ & $\begin{array}{l}\text { Sociology } \\
\text { HM-HV } \\
300-309 \\
360-369\end{array}$ & $\begin{array}{l}\text { Economics } \\
\text { HB-HJ } \\
330-339 \\
380-389\end{array}$ & $\begin{array}{l}\text { History } \\
\text { C-F } \\
900-999 \\
\text { except } \\
910-919\end{array}$ & Other \\
\hline AAA & $\begin{array}{l}15 \\
60\end{array}$ & $\begin{array}{l}0 \\
0\end{array}$ & $\begin{array}{l}0 \\
0\end{array}$ & $\begin{array}{l}0 \\
1\end{array}$ & $\begin{array}{l}0 \\
0\end{array}$ & $\begin{array}{l}22 \\
54\end{array}$ & $\begin{array}{l}4 \\
1\end{array}$ & $\begin{array}{l}40 \\
12\end{array}$ & $\begin{array}{l}19 \\
22\end{array}$ \\
\hline AERA & $\begin{array}{r}0 \\
19\end{array}$ & $\begin{array}{l}75 \\
69\end{array}$ & $\begin{array}{l}0 \\
0\end{array}$ & $\begin{array}{l}0 \\
0\end{array}$ & $\begin{array}{l}6 \\
6\end{array}$ & $\begin{array}{r}6 \\
19\end{array}$ & $\begin{array}{l}0 \\
0\end{array}$ & $\begin{array}{r}13 \\
0\end{array}$ & $\begin{array}{l}0 \\
6\end{array}$ \\
\hline AAG & $\begin{array}{r}0 \\
14\end{array}$ & $\begin{array}{l}0 \\
0\end{array}$ & $\begin{array}{r}7 \\
14\end{array}$ & $\begin{array}{l}0 \\
0\end{array}$ & $\begin{array}{l}0 \\
0\end{array}$ & $\begin{array}{r}7 \\
14\end{array}$ & $\begin{array}{r}14 \\
7\end{array}$ & $\begin{array}{l}43 \\
29\end{array}$ & $\begin{array}{l}29 \\
36\end{array}$ \\
\hline APSA & $\begin{array}{r}0 \\
22\end{array}$ & $\begin{array}{l}1 \\
1\end{array}$ & $\begin{array}{l}0 \\
0\end{array}$ & $\begin{array}{l}50 \\
54\end{array}$ & $\begin{array}{l}0 \\
0\end{array}$ & $\begin{array}{l}18 \\
29\end{array}$ & $\begin{array}{r}11 \\
7\end{array}$ & $\begin{array}{r}13 \\
5\end{array}$ & $\begin{array}{l}6 \\
4\end{array}$ \\
\hline APA & $\begin{array}{r}0 \\
13\end{array}$ & $\begin{array}{l}13 \\
13\end{array}$ & $\begin{array}{l}0 \\
0\end{array}$ & $\begin{array}{l}0 \\
0\end{array}$ & $\begin{array}{l}40 \\
33\end{array}$ & $\begin{array}{r}7 \\
20\end{array}$ & $\begin{array}{l}0 \\
0\end{array}$ & $\begin{array}{l}0 \\
0\end{array}$ & $\begin{array}{l}40 \\
33\end{array}$ \\
\hline ASA & $\begin{array}{r}1 \\
47\end{array}$ & $\begin{array}{l}3 \\
3\end{array}$ & $\begin{array}{l}0 \\
0\end{array}$ & $\begin{array}{c}8 \\
10\end{array}$ & $\begin{array}{l}0 \\
0\end{array}$ & $\begin{array}{l}32 \\
53\end{array}$ & $\begin{array}{l}18 \\
17\end{array}$ & $\begin{array}{r}20 \\
8\end{array}$ & $\begin{array}{l}17 \\
10\end{array}$ \\
\hline \multicolumn{10}{|c|}{$\begin{array}{l}\text { Figures are percentages; not all LCC percentages add up to } 100 \text { percent because of rounding; DDC percentages } \\
\text { include overlap of 300-309 in Sociology and Anthropology } \\
\text { Source: LCC WorldCat, spring 2003; DDC WorldCat, April } 2004 .\end{array}$} \\
\hline
\end{tabular}




\section{TABLE 5}

Subject Distribution of Humanities Prizewinners by LCC and DDC

\begin{tabular}{|c|c|c|c|c|c|c|}
\hline $\begin{array}{l}\text { Awarding } \\
\text { Association }\end{array}$ & $\begin{array}{c}\text { Art } \\
(\mathrm{N}-\mathrm{NX}) \\
700-779\end{array}$ & $\begin{array}{c}\text { History } \\
(\mathrm{C}-\mathrm{F}) \\
900-909 ; \\
921-999\end{array}$ & $\begin{array}{c}\text { Literature } \\
\text { (P-PZ) } \\
400-499 ; \\
800-899\end{array}$ & $\begin{array}{c}\text { Musicology } \\
\text { (M-MT) } \\
780-789\end{array}$ & $\begin{array}{c}\text { Social Science } \\
\text { (G-LT) } \\
\text { 300-399; } \\
910-919\end{array}$ & Other \\
\hline $\begin{array}{l}\text { College Art } \\
\text { Association }\end{array}$ & $\begin{array}{r}91 \% \\
95 \%\end{array}$ & $\begin{array}{l}0 \\
0\end{array}$ & $\begin{array}{r}5 \% \\
0\end{array}$ & $\begin{array}{l}0 \\
0\end{array}$ & $\begin{array}{l}0 \\
0\end{array}$ & $\begin{array}{l}5 \% \\
5 \%\end{array}$ \\
\hline $\begin{array}{l}\text { American } \\
\text { Historical } \\
\text { Association }\end{array}$ & $\begin{array}{l}1 \% \\
2 \%\end{array}$ & $\begin{array}{r}48 \% \\
40 \%\end{array}$ & $\begin{array}{r}1 \% \\
1 \%\end{array}$ & $\begin{array}{l}1 \% \\
1 \%\end{array}$ & $\begin{array}{l}41 \% \\
46 \%\end{array}$ & $\begin{array}{r}9 \% \\
10 \%\end{array}$ \\
\hline $\begin{array}{l}\text { Modern } \\
\text { Language } \\
\text { Association }\end{array}$ & $\begin{array}{l}1 \% \\
3 \%\end{array}$ & $\begin{array}{r}11 \% \\
9 \%\end{array}$ & $\begin{array}{r}73 \% \\
68 \%\end{array}$ & $\begin{array}{l}1 \% \\
1 \%\end{array}$ & $\begin{array}{l}5 \% \\
7 \%\end{array}$ & $\begin{array}{r}8 \% \\
13 \%\end{array}$ \\
\hline $\begin{array}{l}\text { American } \\
\text { Musicological } \\
\text { Society }\end{array}$ & $\begin{array}{l}0 \\
0\end{array}$ & $\begin{array}{l}0 \\
0\end{array}$ & $\begin{array}{l}0 \\
0\end{array}$ & $\begin{array}{r}100 \% \\
92 \%\end{array}$ & $\begin{array}{l}0 \\
0\end{array}$ & $\begin{array}{r}0 \\
8 \%\end{array}$ \\
\hline
\end{tabular}

Not all row totals equal 100 percent because of rounding.

Source: LCC WorldCat, fall 2001; DDC WorldCat, April 2004

ments of Library of Congress Classification (LCC) to the prizewinners generally support that expectation. Except for education, where three-fourths of the books awarded prizes by the AERA class in the LCC category for education (L-LT), no discipline overwhelmingly captures the books awarded by its association. (See table 4.) Political science is the only other discipline where at least half (in this case, 50 percent) of the books receiving prizes are in the classification for the discipline (LCC HX-KKZ). Although not a majority, books that class in LCC BF for psychology are the largest group (40\%) receiving prizes from the APA and books that class in LCC HM-HV for sociology are the largest group (32\%) receiving prizes from the ASA. In geography and anthropology, books that class in history (LCC C-F) are the largest single group with 43 and 40 percent, respectively. Social scientists have written about the influence of economics on other disciplines in the social sciences, particularly its impact through rational choice theory. ${ }^{11}$ Although books that address or utilize rational choice theory can fall in a variety of places in LCC (for example, $\mathrm{BJ}, \mathrm{HB}, \mathrm{HC}, \mathrm{HM}, \mathrm{HV}$, and JC), LCC HB$\mathrm{HJ}$ is the principal place for books on economic topics. Sociology appears to have the greatest interest in economics, with nearly one-fifth of its prizes going to books that classify in LCC HB-HJ. Political science may have noteworthy conflicts about rational choice theory, but it does not extend substantially to topical interest in economics because only about 10 percent of political science prizewinners classify in economics (LCC HB-HJ). ${ }^{12}$

Some might argue that LCC has scattered books in the social sciences outside social science call number areas, especially into C-F for history. Indeed, if one looks at the distribution of Dewey Decimal Classification (DDC) numbers assigned to social sciences prizewinners by WorldCat, one gets a very different picture of the influence of history (900-909 and 920-999 in DDC) (table 4). 
Only geography has more than 20 percent of its prizewinners classed in DDC history. On the other hand, by combining anthropology and sociology in 300-309, DDC prevents distinguishing between these disciplines.

\begin{tabular}{|c|c|c|c|c|c|c|}
\hline \multicolumn{7}{|c|}{$\begin{array}{c}\text { TABLE } 6 \\
\text { Publishers of Books with Greatest WorldCat Holdings }\end{array}$} \\
\hline $\begin{array}{l}\text { WorldCat } \\
\text { Holdings }\end{array}$ & Publisher & Author & Title & $\begin{array}{c}\text { Association } \\
\text { Awarding } \\
\text { Prize }\end{array}$ & $\begin{array}{c}\text { LC } \\
\text { Class }\end{array}$ & Date \\
\hline 3827 & Crown & $\begin{array}{c}\text { Jonathan } \\
\text { Kozol }\end{array}$ & Savage Inequalities & $\begin{array}{l}\text { AERA, } \\
\text { APSA }\end{array}$ & LC & 1991 \\
\hline 2531 & $\begin{array}{l}\text { William } \\
\text { Morrow }\end{array}$ & Steven Pinker & $\begin{array}{l}\text { The Language } \\
\text { Instinct }\end{array}$ & APA & $\mathrm{P}$ & 1994 \\
\hline 2406 & Norton & Steven Pinker & How the Mind Works & APA & QP & 1997 \\
\hline 2060 & Yale & $\begin{array}{c}\text { Joan } \\
\text { DelFattore }\end{array}$ & $\begin{array}{l}\text { What Johnny } \\
\text { Shouldn't Read }\end{array}$ & AERA & LB & 1992 \\
\hline 1705 & Basic Books & $\begin{array}{c}\text { Daniel } \\
\text { Schacter }\end{array}$ & $\begin{array}{l}\text { Searching for } \\
\text { Memory }\end{array}$ & APA & $\mathrm{BF}$ & 1996 \\
\hline 1633 & $\begin{array}{l}\text { Addison- } \\
\text { Wesley }\end{array}$ & $\begin{array}{c}\text { David } \\
\text { Berliner }\end{array}$ & Manufactured Crisis & AERA & LA & 1995 \\
\hline 1573 & Russell Sage & Kathryn Edin & Making Ends Meet & ASA & HQ & 1997 \\
\hline 1525 & $\begin{array}{l}\text { Unwin } \\
\text { Hyman }\end{array}$ & $\begin{array}{l}\text { Patricia } \\
\text { Collins }\end{array}$ & $\begin{array}{l}\text { Black Feminist } \\
\text { Thought }\end{array}$ & ASA & HQ & 1990 \\
\hline 1412 & Harvard & $\begin{array}{l}\text { Douglas Massey, } \\
\text { Nancy Denton }\end{array}$ & American Apartheid & ASA & $\mathrm{E}$ & 1993 \\
\hline 1394 & California & Fay Ginsburg & Contested Lives & ASA & HQ & 1989 \\
\hline 1339 & Oxford & Doug McAdam & Freedom Summer & ASA & $E$ & 1988 \\
\hline 1329 & Chicago & Mitchell Duneier & Slim's Table & ASA & $\mathrm{F}$ & 1992 \\
\hline 1315 & Chicago & Elijah Anderson & Streetwise & ASA & $\mathrm{HN}$ & 1990 \\
\hline 1307 & Yale & Robert Dahl & $\begin{array}{l}\text { Democracy and Its } \\
\text { Critics }\end{array}$ & APSA & $\mathrm{JC}$ & 1989 \\
\hline 1289 & Rutgers & $\begin{array}{l}\text { Camilo } \\
\text { Vergara }\end{array}$ & $\begin{array}{c}\text { New American } \\
\text { Ghetto }\end{array}$ & ASA & $\mathrm{HN}$ & 1995 \\
\hline 1218 & Cambridge & $\begin{array}{l}\text { Phillippe } \\
\text { Bourgois }\end{array}$ & In Search of Respect & AAA & $\mathrm{HV}$ & 1995 \\
\hline 1173 & Jossey-Bass & $\begin{array}{c}\text { Linda Darling- } \\
\text { Hammond }\end{array}$ & Right to Learn & AERA & LB & 1997 \\
\hline 1170 & Norton & $\begin{array}{c}\text { Barbara } \\
\text { Rothman }\end{array}$ & $\begin{array}{l}\text { Recreating } \\
\text { Motherhood }\end{array}$ & ASA & HQ & 1989 \\
\hline 1169 & Cambridge & $\begin{array}{l}\text { Harry } \\
\text { Collins }\end{array}$ & $\begin{array}{c}\text { Golem: What } \\
\text { Everyone Should } \\
\text { Know about Science }\end{array}$ & ASA & Q & 1993 \\
\hline 1145 & $\begin{array}{c}\text { Twayne, } \\
\text { Prentice-Hall }\end{array}$ & $\begin{array}{l}\text { Betty Dobratz, } \\
\text { Stephanie } \\
\text { Shanks-Meile }\end{array}$ & $\begin{array}{c}\text { White Power, White } \\
\text { Pride }\end{array}$ & ASA & $\mathrm{E}$ & 1997 \\
\hline
\end{tabular}


The wide disciplinary distribution of the social sciences prizewinners contrasts with the greater disciplinary focus of the humanities prizewinners. Whether we analyze humanities prizewinners by LC or DDC, all prizewinners, except in history, tend to fall into the classification of their discipline. (See table 5.) Ninety percent or more of art and music prizewinners are classed in their fields, compared to approximately 70 percent of literature prizewinners. History prizewinners are nearly equally represented in history and social sciences classification areas. Perhaps the fact that the objects of artistic, musical, and literary scholarship are normally artifacts that have distinctive characteristics (an observer can differentiate a painting from a score or a novel at a glance) makes it easier to classify a book about, in effect, one of those types of artifacts. In contrast, the objects of study in anthropology, geography (at least human geography), political science, psychology, sociology, and history are people whose behaviors, both individual and collective, have many aspects - anthropological, economic, geographical, political, social, and historical, none of which can be clearly differentiated from the other. (Education may differ because most of what modern societies identify as education is conducted in distinctive institutional settings.) Regardless of the reasons why humanities prizewinners class in a narrower range of fields than social sciences prizewinners, the greater intermingling among the social sciences makes it much easier for libraries to divide up collection development responsibilities among different librarians for the humanities than for the social sciences.

\section{WorldCat Holdings of Prizewinners}

The author's study of humanities prizewinners showed that those from trade publishers disproportionately dominated the group of awardees that were most held by libraries. Although trade books were less than 20 percent of humanities prizewinners, nine of the twenty winners that had the most holding libraries on OCLC's WolrdCat were from trade publishers (Humanities, 366-7). The disproportion is the same in the social sciences, where trade publishers also had less than 20 percent of all winners and produced nine of the twenty most held. (See table 6.) In addition, one of the most widely held social sciences awardees was from a foundation, Russell Sage.

Overall, the twenty most-held social sciences prizewinners were more widely held than the twenty most-held humanities prizewinners. In April 2004, the mean number of holdings for the social sciences top twenty was 1,626 and the median was 1,367 . For the twenty most-held humanities prizewinners, the mean holding was 1,398 and the median was 1,215 . To place the figures on most-held social sciences prizewinners in another context, one can compare them to the top ten mid-decade (1995) hardcover nonfiction best-sellers from Publisher's Weekly that averaged 2,539 (median 2,196) WorldCat holdings in May 2004. ${ }^{13}$

Although some social sciences prizewinners have impressive library acquisitions, the typical prizewinner is far from a best-seller: the mean WorldCat holdings for all awardees is 564 and the median is 454. This contrasts favorably with comparable numbers for humanities prizewinners: a mean of 482 and a median of 378. These numbers include all WorldCat records for print editions, including those for translations, paperback editions, and the like. Because most academic libraries enter their holdings on WorldCat, the data found here reinforce the point that academic publishers can no longer count on substantial sales to academic libraries of any book they produce. 
The social sciences prizewinners published between 1987 and 1992 have mean WorldCat holdings of 617 (median 514); those published between 1993 and 1995 have a mean of 546 (median 458); and those published between 1996 and 1998 have a mean of 536 (median 415). Humanities prizewinners published in 1992 or earlier average 531 holdings (median 454); those published between 1993 and 1995

\begin{tabular}{|c|c|c|c|c|}
\hline \multicolumn{5}{|c|}{$\begin{array}{c}\text { TABLE } 7 \\
\text { WorldCat Holdings of Social Sciences Prizewinners } \\
\text { by Awarding Association }\end{array}$} \\
\hline $\begin{array}{c}\text { Awarding } \\
\text { Association }\end{array}$ & $\begin{array}{l}\text { Number of } \\
\text { Winning } \\
\text { Books }\end{array}$ & $\begin{array}{c}\text { Mean } \\
\text { Holdings }\end{array}$ & $\begin{array}{l}\text { Median } \\
\text { Holdings }\end{array}$ & $\begin{array}{l}\text { Range of } \\
\text { Holdings }\end{array}$ \\
\hline AAA & 68 & 471 & 363 & $182-1,218$ \\
\hline AERA & 16 & 1,001 & & $179-3,827$ \\
\hline AAG & 4 & 449 & 417 & $92-948$ \\
\hline APSA & 142 & 552 & 472 & $181-3,827 *$ \\
\hline APA & 15 & 985 & 769 & $194-2,531$ \\
\hline ASA & 132 & 558 & 454 & $121-1,573^{* *}$ \\
\hline \multicolumn{5}{|c|}{$\begin{array}{l}\text { Five books received prizes from two associations. } \\
* \text { Mean and median holdings of APSA association-wide prizewinners } \\
\text { are } 683 \text { and } 652 \text {. } \\
\text { ** Mean and median holdings of ASA association-wide prizewinners } \\
\text { are } 786 \text { and } 609 .\end{array}$} \\
\hline \multicolumn{5}{|c|}{ Source: WorldCat, April 2004.} \\
\hline
\end{tabular}
average 496 holdings (median 387); and those published between 1996 and 1998 average 447 holdings (median 351). The percentage of decline in holdings between 1987-1992 and 1996-1998 is slightly lower for the social sciences (19\% of the median) than for the humanities (23\%).

Of some interest are the relative holdings in WorldCat of the prizewinners of the different associations. AERA and APA winners have the largest mean and median holdings, 1,001/811 and 985/769, respectively (table 7 ), but comparison to other disciplines must take into account the fact that AERA and APA association-wide awards dominate (20 of 31, or 65 percent). Nevertheless, the very high mean holdings for education and psychology suggest that these disciplines touch on topics of interest not only to scholars, but also to the general public. More narrowly cast divisional prizes predominate for AAA, APSA, and ASA, such that only 57 of 342 prize-winning books (17\%) are at the association level. In fact, AAA has no association-wide book prizes. For APSA and ASA, the mean/median WorldCat

holdings of association-wide winners are 683/652 and 786/651, respectively (table 7).

\section{Electronic Versions of Prizewinners}

WorldCat offers data on the availability of books through netLibrary. When launched in 1999, netLibrary described itself as the "leading provider of eBooks." It aimed to provide "a comprehensive collection of reference, scholarly, and professional electronic books." ${ }^{14}$ After financial difficulty, netLibrary was acquired by OCLC in 2002. Although e-books are available online from sources other than netLibrary, at the time of this writing (April 2004), none of those sources began to match netLibrary's coverage of the prizewinners that are the subject of this article. Ebrary, an aggregator comparable to netLibrary, offered online nine prizewinners from four different publishers. ${ }^{15}$ Publishers themselves-California (19), Princeton (8), and Oxford (1) - provided twentyeight. In April 2004, Ebrary and publishers provided access to only one prizewinner not supplied by netLibrary. Online 
availability of prizewinners is growing, but, at the time of this writing, the best single way to analyze online availability of 1990s social sciences prizewinners is to study books supplied by netLibrary.

Overall, 19 percent (71 of 382 unique books) of the prize-winning books in the present study were listed as available from netLibrary in April 2004. (Between spring 2003 and April 2004, netLibrary added one social sciences prizewinner from the 1990s.) The mean and median holdings for a netLibrary social sciences awardee are 245 and 214 , respectively. For eighteen books, WorldCat listed more holdings in netLibrary than in paper copies. Just as the University of California Press made the most humanities prizewinners accessible through netLibrary, so, too, it had the most social sciences prizewinners available from netLibrary - twenty-five of thirty-three different books (Humanities, 370). (See table 8.) The next greatest was eight of the Yale University Press's twenty-two different prizewinners and seven of Princeton University Press's thirty-five different prizewinning books. netLibrary also mounted five of the SUNY Press's six winning books. Otherwise, most presses were represented, if at all by spring 2004, by no more than three books. Notably missing from the netLibrary collection were some publishers that had five or more prizewinners, led by the University of Chicago Press (forty prizes) (tables 3 and 8). Also notable among the missing were trade publishers. Among the more than sixty unique books from trade publishers that won prizes, only five had WorldCat holdings for netLibrary.

In terms of subject area of all netLibrary books as reflected in LCC and DDC assigned to them, coverage ranged from one percent that class in LCC for psychology and geography to 27 percent in history and in DDC zero percent for geography to 34 percent for anthropology and sociology. (See table 9.) These percentages among the netLibrary books

\begin{tabular}{|l|c|c|}
\hline \multicolumn{3}{|c|}{$\begin{array}{c}\text { TABLE } 8 \\
\text { Publishers Providing Award-winning Social } \\
\text { Sciences Books for netLibrary }\end{array}$} \\
\hline \hline Publisher & $\begin{array}{c}\text { Number of } \\
\text { netLibrary } \\
\text { Titles }\end{array}$ & $\begin{array}{c}\text { Number of Prizes } \\
\text { Won/Number of Books } \\
\text { Winning Prizes* }\end{array}$ \\
\hline California & 25 & $36 / 33$ \\
\hline Yale & 8 & $25 / 22$ \\
\hline Princeton & 7 & $38 / 35$ \\
\hline SUNY & 5 & $6 / 6$ \\
\hline Cambridge & 3 & $29 / 27$ \\
\hline Oxford & 3 & $18 / 17$ \\
\hline Beacon & 2 & $4 / 4$ \\
\hline Brookings & 2 & $4 / 3$ \\
\hline Nebraska & 2 & $3 / 3$ \\
\hline New Mexico & 2 & $2 / 2$ \\
\hline Pennsylvania & 2 & $3 / 3$ \\
\hline Basic & 1 & $6 / 6$ \\
\hline Columbia & 1 & $6 / 6$ \\
\hline Erlbaum & 1 & $2 / 2$ \\
\hline Iowa & 1 & $1 / 1$ \\
\hline MIT & 1 & $2 / 2$ \\
\hline North Carolina & 1 & $3 / 3$ \\
\hline NYU & 1 & $1 / 1$ \\
\hline Oklahoma & 1 & \\
\hline Rutgers & 1 & \\
\hline Unwin Hyman & 1 & \\
\hline * Some books won more than one prize. \\
Source: WorldCat, April 2004.
\end{tabular}




\begin{tabular}{|c|c|c|}
\hline \multicolumn{3}{|c|}{$\begin{array}{c}\text { TABLE 9 } \\
\text { Social Sciences Prize-winning Books Available through netLibrary by } \\
\text { LCC, DDC, and Awarding Association }\end{array}$} \\
\hline LC/DDC Classification Range & $\begin{array}{l}\text { Percentage of } \mathrm{LCC} / \mathrm{DDC} \\
\text { or Association among all } \\
\text { Prizewinners } \\
\end{array}$ & $\begin{array}{c}\text { Percentage of LCC/DDC or } \\
\text { Association among all netLibrary } \\
\text { Available Prizewinners } \\
\end{array}$ \\
\hline AAA (anthropology) & 18 & 25 \\
\hline $\begin{array}{l}\text { GN-GT/300-309, } \\
\text { 390-399 (anthropology) }\end{array}$ & $3 / 36$ & $4 / 34$ \\
\hline AERA (education) & 4 & 6 \\
\hline L-LT/370-379 (education) & $5 / 5$ & $7 / 7$ \\
\hline AAG (geography) & 4 & 6 \\
\hline G-GF/910-919 (geography) & $0 * / 1$ & $1 / 0$ \\
\hline APSA (political sci.) & 37 & 26 \\
\hline $\begin{array}{l}\mathrm{HX}-\mathrm{KKZ} / 320-329,340-349, \\
350-359 \text { (political science) }\end{array}$ & $21 / 24$ & $20 / 20$ \\
\hline APA (psychology) & 4 & 0 \\
\hline BF/150-159 (psychology) & $2 / 2$ & $1 / 1$ \\
\hline ASA (sociology) & 34 & 38 \\
\hline $\begin{array}{l}\mathrm{HM}-\mathrm{HV} / 300-309,360-369 \\
\text { (sociology) }\end{array}$ & $22 / 40$ & $17 / 34$ \\
\hline $\begin{array}{l}\mathrm{HB}-\mathrm{HJ} / 330-339,380-389 \\
\text { (economics) }\end{array}$ & $12 / 9$ & $8 / 6$ \\
\hline $\begin{array}{l}\mathrm{C}-\mathrm{F} / 900-909,920-999 \\
\text { (history) }\end{array}$ & $21 / 8$ & $27 / 11$ \\
\hline Other & $14 / 12$ & $15 / 18$ \\
\hline \multicolumn{3}{|c|}{$\begin{array}{l}\text { *One prize-winning book classed in geography in LCC, too few to constitute one percent } \\
\text { of all prize-winning books. } \\
\text { Percentages for awarding associations are in italic. } \\
\text { Source: WorldCat, LCC, spring 2003, DDC April } 2004 \text {. }\end{array}$} \\
\hline
\end{tabular}

are quite close to the subject distribution by LCC and DDC among all prizewinners. In terms of awarding association, no APA winner was accessible through netLibrary, compared to 38 percent of ASA awardees. AAA, and especially APSA, stand out, when comparing the percentage of each association's winners among all winners and the percentage of each association's winners among netLibrary-supplied books. AAA's share of netLibrary-supplied prizewinners is greater than its portion of all prizewin- ners; APSA's share of netLibrary titles is notably smaller. In both cases, the University of California Press may make the difference. It received more prizes (nine) from the AAA than any other publisher, eight of which are accessible through netLibrary. In contrast, California published only two APSA awardees, both available from netLibrary.

\section{Conclusion}

As was true of the author's study of humanities prizewinners, the study of 
prize-winning books from six major scholarly associations in the social sciences reinforces some things that are well known, points to recently identified developments, and offers insight into new phenomena. There are many similarities and a few differences between prize-winning books in the humanities and those in the social sciences. Table 10 summarizes key comparisons. First,

\begin{tabular}{|c|c|c|c|}
\hline \multicolumn{4}{|c|}{$\begin{array}{c}\text { TABLE } 10 \\
\text { Comparison of 1990s Prize-winning Books in the } \\
\text { Humanities and Social Sciences }\end{array}$} \\
\hline & $\begin{array}{l}\text { Humanities } \\
\text { Prizewinners }\end{array}$ & $\begin{array}{l}\text { Social Sciences } \\
\text { Prizewinners }\end{array}$ & $\%$ Difference \\
\hline Number of prizes awarded & 328 & 412 & 26 \\
\hline Number of books receiving prizes & $323 *$ & $382 * *$ & 18 \\
\hline$\%$ of books coauthored & 7 & 16 & 129 \\
\hline Mean number of authors per book & 1.1 & 1.2 & 8 \\
\hline Number of authors winning $>1$ prize & $7(2 \%)$ & $45(10 \%)$ & 400 \\
\hline $\begin{array}{l}\% \text { of books written by authors from } \\
20 \% \text { of institutions }\end{array}$ & 52 & 58 & 12 \\
\hline $\begin{array}{l}\% \text { of books published by } 20 \% \text { of } \\
\text { publishers }\end{array}$ & 72 & 67 & -7 \\
\hline$\%$ of books from university presses & 84 & 81 & -4 \\
\hline$\%$ of books supplied by netLibrary & 20 & 19 & -5 \\
\hline $\begin{array}{l}\text { Mean/median number of WorldCat } \\
\text { holdings all books }\end{array}$ & $482 / 378$ & $566 / 450$ & $17 / 19$ \\
\hline $\begin{array}{l}\text { Mean/median number of WorldCat } \\
\text { holdings, 1987-1992 imprints }\end{array}$ & $531 / 454$ & $617 / 514$ & $16 / 13$ \\
\hline $\begin{array}{l}\text { Mean/median number of WorldCat } \\
\text { holdings, 1993-1995 imprints }\end{array}$ & $496 / 387$ & $546 / 458$ & $10 / 18$ \\
\hline $\begin{array}{l}\text { Mean/median number of WorldCat } \\
\text { holdings, 1996-1998 imprints }\end{array}$ & $447 / 351$ & $536 / 415$ & $20 / 18$ \\
\hline \multicolumn{4}{|c|}{$\begin{array}{l}\text { Humanities prizewinners awarded by College Art Assoc.(22), American Historical Assoc. } \\
\text { (145), American Musicological Soc. (13), Modern Language Assoc. (148). } \\
\text { Social sciences prizewinners awarded by American Anthropological Assoc.(72), Ameri- } \\
\text { can Educational Research Assoc. (16), Assoc. of American Geographers (14), American } \\
\text { Political Science Assoc. (154), American Psychological Assoc. (15), American Sociologi- } \\
\text { cal Assoc. (141). }\end{array}$} \\
\hline \multicolumn{4}{|c|}{$\begin{array}{l}\text { WorldCat holdings are for April 2004. Calculations of means and medians in Humanities, } \\
368 \text { were based on all prizes won, so holdings for some books were counted twice. This } \\
\text { article calculates means and medians for unique books, so books that won more than one } \\
\text { prize are considered only once. This method of calculation lowers means and medians } \\
\text { because multiple prizewinners tend to have higher WorldCat holdings. }\end{array}$} \\
\hline $\begin{array}{l}\text { *Five books won two prizes; no book } \\
\text { ** Twenty-six books won two prizes; } \\
\text { from two associations. }\end{array}$ & $\begin{array}{l}n \text { prizes from } \\
\text { books won }\end{array}$ & o associations. & ks won prizes \\
\hline
\end{tabular}


the data show more than twice as much coauthorship in the social sciences as in the humanities (16\% versus $7 \%$ ). Still, the mean number of authors is similar for both the social sciences (1.2) and the humanities (1.1), indicating that single authorship remains the norm for social sciences books. Further, coauthorship of books in the social sciences is far behind coauthorship of articles. Over 40 percent of the articles published in 1990, 1993, and 1996 in the flagship journals (American Anthropologist, American Political Science Review, and American Sociological Review) of the three associations (AAA, APSA, and ASA) that supplied nearly 90 percent of the prizewinners are coauthored. In short, coauthorship is more prevalent in the social sciences than in the humanities, but much less prevalent among social sciences books than among social sciences journal articles.

Second, library holdings of prizewinners declined during the 1990s in both the humanities and the social sciences. The humanities saw a slightly greater decline than the social sciences did. The mean holdings of humanities prize-winning books published between 1996 and 1998 was 16 percent lower than the mean holdings for those published between 1987 and 1992; the comparable percentage for social sciences prizewinners is 13 percent. The median holdings of humanities prize-winning books declined about 23 percent, compared to 19 percent for the social sciences prizewinners. In terms of the health of the academy (its scholars, libraries, and publishers), this decline is the single most important finding of this study.

Third, most prize-winning scholarship in both the humanities and the social sciences comes from major university presses and the largest, traditionally dominant research universities. The social sciences have slightly more concentra- tion in institutions than the humanities: 52 percent of humanities prizewinners come from the top 20 percent of institutions, whereas 58 percent of the social sciences prizewinners come from the top 20 percent of institutions. There is greater concentration among publishers than institutions, and the social sciences have slightly less concentration in publishers than the humanities. Sixty-seven percent of the social sciences prizewinners came from the top 20 percent of publishers, whereas 72 percent of humanities prizewinners came from the top 21 percent of publishers. In the humanities, 84 percent of prizewinners were published by university presses, whereas 81 percent of social sciences prizewinners were published by university presses.

Through all the rankings, the University of California, especially its Berkeley campus, and the university's press stand out. When humanities and social sciences prizes to publishers are combined, the University of California Press ranks first with sixty-three. Only Princeton University Press, with sixty-one, and the University of Chicago Press, with sixty, are close. When considering prizes in relation to institutions, the University of California has an even greater presence in the social sciences than in the humanities. Its Berkeley, Los Angeles, and Santa Barbara campuses that were among the top ten prize-winning institutions in the humanities are among the top twenty-two prize-winning institutions in the social sciences, along with the campuses at San Diego, Davis, and Santa Cruz. Overall, public institutions have a greater presence among the top twenty or so prizewinners in the social sciences $(59 \%)$ than in the humanities (47\%).

Geographically, with six University of California campuses and Stanford and with five Ivy League institutions, Duke, and Rutgers, coastal states have a substan- 
tial presence among the top twenty-two social sciences prize-winning institutions. But the East and West Coasts were even more dominant in the humanities, taking fourteen of the nineteen top positions. Wisconsin, Chicago, and Texas carry over from the top humanities prizewinners to the top social sciences prizewinners; and Michigan, Northwestern, Colorado, Indiana, and Minnesota, from the center of the country, join them. Looked at another way, all institutions from the West Coast among the top humanities prizewinners were also top social sciences prizewinners. Five top humanities prizewinners from the East Coast did not rank among the top social sciences prizewinners, and only two East Coast institutions replaced them. In moving from the humanities to the social sciences, there is a geographical shift toward the West.

As was true among humanities prizewinners, although university press books overwhelm trade books in the total population of social sciences prizewinners, trade publishers are disproportionately represented among social sciences awardees with the greatest number of WorldCat holdings. Although trade books are less than 20 percent of all prize-winning books, they constitute 45 percent of the twenty books with greatest WorldCat holdings. Interestingly, trade books are underrepresented among those that have been made accessible by netLibrary. Only five of seventy-one netLibrary books (7\%) are from trade publishers.

The seventy-one books that netLibrary supplied in 2003 are 19 percent of all social sciences prizewinners. In 2004, netLibrary supplied 20 percent of humanities prizewinners, roughly two-thirds of which were in LCC areas for history and social sciences. The high proportion of history- and social sciences-related books among humanities prizewinners suggests that a group of social sciences prizewinners should have had a higher percentage of its number in netLibrary than a group of humanities prizewinners. Compared to social sciences journals, the social sciences prizewinners also seem behind. In late 2003, data from Ulrich's Periodicals Directory reported that 56 percent of refereed journals in anthropology, education, geography, political science, psychology, and sociology were available in electronic format, about three times the percentage of prize-winning books available from netLibrary.

Although the percentage of prizewinners covered by netLibrary is arguably small, it may tell us little about the future electronic availability of scholarly books. Both aggregators other than netLibrary and publishers themselves now offer electronic versions of books. Ebrary, for example, in April 2004, reported partnerships with eleven of the twenty-one publishers that won the most social sciences prizes in the 1990s. ${ }^{16}$ An examination of the Web sites of the publishers of prize-winning books in April 2004 reveals that at least eleven offer e-books themselves. In short, electronic access to books is increasing and the paths to access are varied. Electronic access should bring prize-winning books greater attention, but whether scholars themselves will read e-books is an open question. Research by Janet P. Palmer and Mark Sandler suggests that social scientists are far less enthusiastic about e-books than e-journals. ${ }^{17}$ Whatever happens to e-books, social scientists-especially anthropologists, political scientists, and sociologists - need to monitor trends in book publishing closely, because the health of their disciplines, their libraries and their publishers, and the careers of scholars, especially junior scholars, hang in the balance. 


\section{Notes}

1. Stephen E. Wiberley Jr., "The Humanities: Who Won the '90s in Scholarly Book Publishing," portal: Libraries and the Academy 2 (July 2002): 357-74. (Hereafter cited within the text as Humanities, page number.)

2. On the problem of using bibliographic databases such as WorldCat for analysis of academic publications, see Calvin C. Jones, "Evaluation of Existing Datasets for Policy Research on Humanities Fields," in Robert M. Solow et al., Making the Humanities Count: The Importance of Data (Cambridge, Mass.: American Academy of Arts and Sciences, 2002), 42-46.

3. Neil J. Smelser, Sociology (Cambridge, Mass. and Oxford, Eng.: Blackwell and UNSECO, 1994), 11.

4. William H. Webb et al., Sources of Information in the Social Sciences: A Guide to the Literature 3rd ed. (Chicago: ALA, 1986). This volume includes a chapter by Wiley J. Williams titled "Economics and Business Administration," in which business administration is not treated as an equal of economics. Instead, the chapter treats different aspects of business administration (e.g., management) as subdivisions of economics. Webb also has a chapter on history, a discipline that the author's article on humanities prizewinners covers.

5. Roger G. Baldwin and Ann E. Austin, "Toward Greater Understanding of Faculty Research Collaboration," Review of Higher Education 19 (fall 1995): 45-70.

6. The Web sites of the associations list many of the AAA, AERA, AAG, and APA winners. Members of the associations who had served on prize-selection committees supplied names of other winners. Kenneth D. Madsen sent a complete list of awardees of the AAG J. B. Jackson prize. See Madsen's "Writing for Non-Geographers: Lessons from the J. B. Jackson Prize," Geographical Review 92 (Jan. 2002): 63-72. Winners of prizes from the APSA are listed in the December issues of PS. Michael Murphy of the ASA sent complete listings of all his association's prizewinners. The author is very grateful to association members, Kenneth Madsen, and Michael Murphy for their generosity.

7. Research-Doctorate Programs in the United States: Continuity and Change, ed. Marvin L. Goldberger, Brendan A. Maher, and Pamela Ebert Flattau (Washington, D.C.: National Academy Pr., 1995), 475-77, 542-43, 602-5, 607-13, 616-19.

8. Edward A. Goedeken, "An Index to Publisher Quality Revisited: A Partial Replication," Library Acquisitions: Practice E Theory 17 (1993): 263-68.

9. Paul Metz and John Stemmer, "A Reputational Study of Academic Publishers," College $\mathcal{E}$ Research Libraries 57 (May 1996): 234-47.

10. Political Science: The State of the Discipline, ed. Ira Katznelson and Helen V. Milner (New York, London, and Washington, D.C.: W. W. Norton \& Co. and American Political Science Association, 2002), for example, 37-38, 79, 89, 109, 127-28, 470-72, 475, 479, 482; Smelser, Sociology 3-4, 13-14, 76, 110,131-34, 223, 262, 306, 320-28, 331.

11. Smelser, "The Rational and the Ambivalent in the Social Sciences," American Sociological Review 63 (Feb. 1998): 1-16; Michael Hechter and Satoshi Kanazawa, "Sociological Rational Choice Theory," Annual Review of Sociology 23 (1997): 191-214.

12. D. W. Miller, "Storming the Palace in Political Science," Chronicle of Higher Education (Sept. 21, 2001). Available online at http://chronicle.com/weekly/v48/i04/04a01601.htm.

13. Daisy Maryles, “The Name Is the Game," Publishers Weekly 243 (Mar. 4, 1996): S5.

14. "netLibrary Launches the World's Most Comprehensive Library on the Internet," press release, Mar. 29, 1999.

15. http://www.ebrary.com/publishers/list.jsp.

16. Ibid.

17. Janet P. Palmer and Mark Sandler, "What Do Faculty Want?" Library Journal 128 (winter 2003): 26-28 (Net Connect issue). 